\title{
A CONTRIBUTION TO THE IDENTIFICATION OF CHARCOAL ORIGIN IN BRAZIL I - ANATOMICAL CHARACTERIZATION OF CORYMBIA AND EUCALYPTUS
}

\author{
Thaís Alves Pereira Gonçalves ${ }^{1, \AA}$, Adriano Wagner Ballarin², Silvana Nisgoski, \\ Graciela Inés Bolzon de Muñiz
}

\begin{abstract}
Charcoal is one of the main forestry products and Brazil is the world's largest producer. Its production from native species is estimated at 30-35\% of total output. One of the major problems of the iron and steel industry is charcoal consumption, especially in terms of environmental and social aspects. Therefore, the use of reforestation species must be increased. Considering most of the energy forests in Brazil are planted with eucalyptus, the present work aims to contribute to the identification of charcoal origin through anatomical analysis of Eucalyptus and Corymbia. The wood samples were carbonized in a muffle furnace during $7 \mathrm{~h}$ to a maximum of $450^{\circ} \mathrm{C}$. Anatomical analysis was done according to IAWA Committee. We found few works with charcoal anatomy and the species analyzed were not characterized. The results on charcoal are very close to previous studies of wood anatomy. But, we recommend the comparison of materials of similar features, enhancing the visual acuity, particularities of each material and modifications that might happen. We believe that this analysis is an accurate tool to identify the source of charcoal and can help to guarantee the sustainability of the charcoal supply chain.
\end{abstract}

Keywords: Anatomy, charcoal, eucalyptus, sustainability.

\section{INTRODUCTION}

Sustainability has been a popular subject in recent years, attracting attention from researchers, environmentalists and leaders, including at important global events such as "Rio +20 ". Sustainable development can be defined as "the development that meets the needs of the present without compromising the ability of future generations to meet their own needs" (WCED 1987). The application of this concept in forestry should consider a close association between nature conservation and forest management based on technology as well as economic and social considerations.

Charcoal is one of the main forestry products and Brazil is the world's largest producer (FAO 2012). This biofuel is very important in the national energy mix and almost $90 \%$ of production goes to the iron and steel industry (Brasil 2012a). When charcoal is produced from planted forests, carbon credits are generated along with income in a politically correct way (ABRAF 2012). Despite this, the charcoal supply chain still has negative features, e.g.: (i) unspecialized workers, including children, often working under slave-like conditions; and (ii) illegal cutting of native forests (Carneiro 2008, IOS 2011a, IOS2011b).

\footnotetext{
${ }^{1}$ Engenheira Florestal, Doutoranda. UFPR - Universidade Federal do Paraná, Departamento de Engenharia e Tecnologia Florestal. Curitiba, PR - Brasil

${ }^{2}$ Dr. Engenheiro Civil. UNESP - Universidade Estadual Paulista Júlio de Mesquita Filho, Faculdade de Ciências Agronômicas de Botucatu,

Departamento de Engenharia Rural. Botucatu, SP - Brasil.

${ }^{3}$ Dra. Eng. Florestal. Universidade Federal do Paraná. Curitiba, PR - Brasil.

^ Corresponding author: th_goncalves@yahoo.com.br

Received: 07.05. 2013 Accepted: 29.10. 2013
} 
The production of charcoal from native species in Brazil is estimated to account for $30-35 \%$ of total output (IBGE 2010, ABRAF 2012). Considering the size of the country and additionally the difficulty of effective control of deforestation, we believe that the percentage of charcoal produced from illegally cut native species is even higher. In fact, one of the major problems of the iron and steel industry is charcoal production. In practice, there is no selection on native species for charcoal production, practically all the species goes to the carbonization oven. It is problematic in terms of environmental and social aspects, so the use of reforestation species must be increased (IOS 2011b, Brasil 2012b).

Brazil had 4,87 million hectares of planted eucalypts forests in 2011, using $18,4 \%$ of it to produce charcoal for the steel sector (ABRAF 2012). In general, the term "eucalyptus" is used to refer to about 900 species distributed in two major lineages: (i) Angophora and Corymbia; (ii) Eucalyptus "sensu stricto" - with the subgenera Eudesmia, Symphyomyrtus and Monocalyptus; Eucalyptus and Corymbia are the most abundant genera, having over 700 and about 130 species, respectively (Hill and Johnson 1995, Rozefelds 1996, Euclid 2006).

The present work aims to contribute for the control of charcoal production from native forests in Brazil through anatomical characterization of charcoal made from species of Eucalyptus and Corymbia. It is justified by: (i) the need to increase the use of planted species for charcoal production; (ii) the fact that most energy forests in Brazil are planted with eucalyptus; (iii) the importance of controlling the illegal production of charcoal from native species.

\section{MATERIAL AND METHODS}

Wood samples of Corymbia spp and Eucalyptus spp lumber were donated by Prema - a forestry firm in the city of Rio Claro, São Paulo state. Table 1 shows the data on the species studied.

Table 1. Data on the species.

\begin{tabular}{|c|c|c|}
\hline Species & Origin & $\begin{array}{l}\text { Year } \\
\text { Planted }\end{array}$ \\
\hline $\begin{array}{c}\text { C. citriodora } \\
\text { (Hook.) K.D. Hill \& L.A.S. Johnson }\end{array}$ & $\begin{array}{l}\text { Floresta Estadual de } \\
\text { Pederneiras - SP } \\
\left(22^{\circ} 22^{\prime} \text { S } 40^{\circ} 44^{\prime} \mathrm{W}\right)\end{array}$ & 1966 \\
\hline $\begin{array}{c}\text { C. maculata } \\
\text { (Hook.) K.D. Hill \& L.A.S. Johnson }\end{array}$ & $\begin{array}{c}\text { Floresta Estadual de Rio } \\
\text { Claro - SP } \\
\left(22^{\circ} 25^{\prime} \mathrm{S} 47^{\circ} 33^{\prime} \mathrm{W}\right)\end{array}$ & 1975 \\
\hline $\begin{array}{l}\text { E. dunnii } \\
\text { Maiden }\end{array}$ & $\begin{array}{c}\text { Reflorestamento Klabin, } \\
\text { Telêmaco Borba - PR } \\
\left(24^{\circ} 16^{\prime} \mathrm{S} 50^{\circ} 31^{\prime} \mathrm{W}\right)\end{array}$ & $\begin{array}{l}1987- \\
1990\end{array}$ \\
\hline $\begin{array}{l}\text { E. microcorys } \\
\text { F. Muell. }\end{array}$ & $\begin{array}{c}\text { Floresta Estadual de Rio } \\
\text { Claro - SP } \\
\left(22^{\circ} 25^{\prime} \mathrm{S} 47^{\circ} 33^{\prime} \mathrm{W}\right)\end{array}$ & 1975 \\
\hline $\begin{array}{l}\text { E. saligna } \\
\mathrm{Sm} \text {. }\end{array}$ & $\begin{array}{c}\text { Fazenda Mariana, Araras - } \\
\text { SP } \\
\left(22^{\circ} 17^{\prime} \mathrm{S} 47^{\circ} 15^{\prime} \mathrm{W}\right)\end{array}$ & 1960 \\
\hline $\begin{array}{l}\text { E. tereticornis } \\
\mathrm{Sm} .\end{array}$ & $\begin{array}{l}\text { Fazenda Santa Elisa, } \\
\text { Campanha - MG } \\
\left(22^{\circ} 25^{\prime} \mathrm{S} 47^{\circ} 33^{\prime} \mathrm{W}\right)\end{array}$ & 1970 \\
\hline $\begin{array}{l}\text { E. viminalis } \\
\text { Labill. }\end{array}$ & $\begin{array}{l}\text { Fazenda Santa Maria, } \\
\text { Guarapuava - PR } \\
\left(25^{\circ} 07^{\prime} \mathrm{S} 51^{\circ} 30 \mathrm{~W}\right)\end{array}$ & 1990 \\
\hline
\end{tabular}


For the carbonization, we took random parts of the lumbers and cut samples of $\sim 3-5 \times 10-6 \mathrm{~m}^{3}$. Lumber was randomly sampled from the trees simulating the real conditions of charcoal identification in the field. The samples were wrapped in aluminum foil and carbonized in a muffle furnace (Gonçalves et al. 2012). The carbonization process lasted $5 \mathrm{~h}$, with a final temperature of $450{ }^{\circ} \mathrm{C}$ and heating rate of 1,66 ${ }^{\circ} \mathrm{C} / \mathrm{min}$; the samples remained at the final temperature for $2 \mathrm{~h}$ (Muñiz et al. 2012). The resulting charcoal samples were manually broken and analyzed with a Zeiss Discovery V12 stereomicroscope. Images of the charcoal samples were processed by the Axio Vision Release 4.7 software and measurements of anatomical features were made using them. For the scanning electron microscope (SEM) micrographs the charcoals were fixed with a conductive carbon double-side tape into traditional SEM stubs. The images were obtained directly from the material, without coating, in a Hitachi TM-1000 tabletop microscope.

The descriptions and measurements of wood and charcoal anatomy followed the IAWA Committee (1989) recommendations. Tangential vessel diameter $(\mu \mathrm{m})$ was calculated from 25 measurements; 10 measurements were taken for vessel frequency (vessels $/ \mathrm{mm}^{2}$ ), ray frequency (rays $/ \mathrm{mm}$ ), ray width $(\mu \mathrm{m})$, and ray height $(\mu \mathrm{m})$. The results are presented as mean values (minimum-maximum), standard deviation and unit.

The charcoals micrographs of transverse section (a), longitudinal tangential (b) and radial (c) planes follow the descriptions. We use arrows to show some ruptures.

\section{RESULTS}

The anatomical characterization is presented for each species in the sequence. All the pictures are after the descriptions, they are close to each other to facilitate the comparison between the species. The anatomical characteristics of main importance are summarized in table 2.

Plate 1: Corymbia citriodora (Hook.) K.D. Hill \& L.A.S. Johnson (Figures 1a, 1b, 1c)

Growth rings: present, demarcated by thick-walled and radially flattened fibers.

Vessels: wood diffuse-porous; diagonal pattern; solitary and multiples; 133 (83-212) $29 \mu \mathrm{m} ; 12$ (8-19) 4 vessels $/ \mathrm{mm}^{2}$; tyloses present; simple perforation plates; alternate intervessel pits, vestured.

Axial parenchyma: mostly vasicentric, confluent, diffuse and diffuse-in-aggregates, tendency to form lines, few lozenge-aliform; 4-8 cells per strand.

Rays: 1-2-seriate; 23 (11-38) $8 \mu \mathrm{m}$ width; 193 (120-317) $60 \mu \mathrm{m}$ height; 12 (7-17) 2 rays/mm; all cells procumbent.

Fibers: non-septate; very thin to thick-walled.

Mineral inclusions: prismatic crystals in chambered axial parenchyma cells and fibers.

Ruptures: present in rays. 

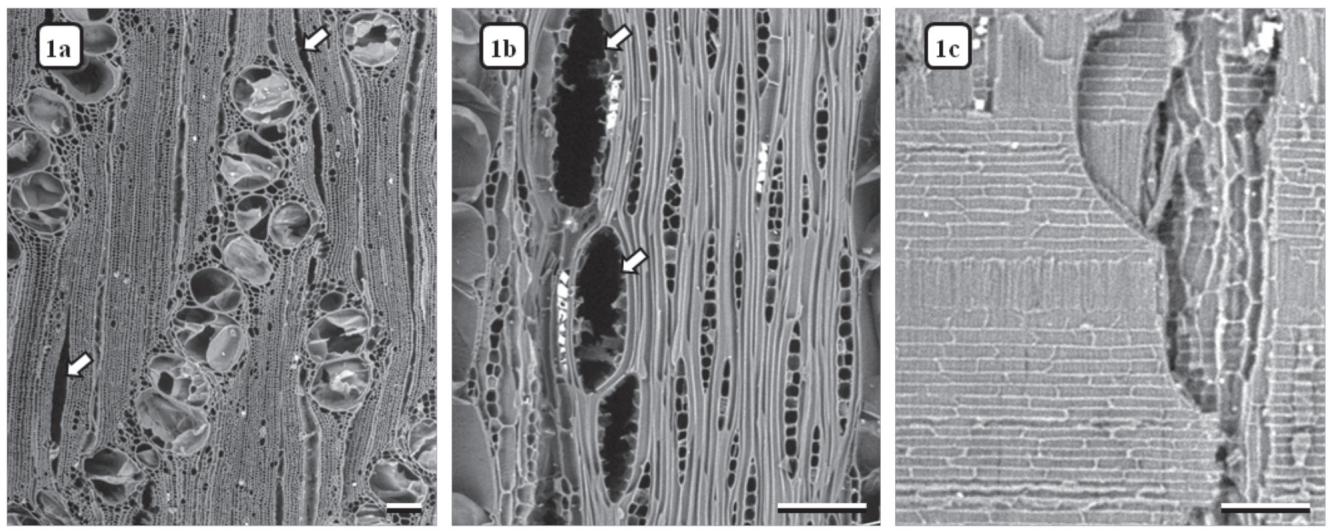

Figure 1. Plate 1. Corymbia citriodora. Charcoal micrographs.

Arrows show the ruptures. Sections (a) Transverse, (b) Tangential Longitudinal, (c) Radial Longitudinal. Bars: $100 \mu \mathrm{m}$.

Plate 2: Corymbia maculata (Hook.) K.D. Hill \& L.A.S. Johnson (Figures 2a, 2b, 2c)

Growth rings: present, demarcated by thick-walled and radially flattened fibers.

Vessels: wood diffuse-porous; diagonal pattern; solitary and multiples; 149 (102-202) $25 \mu \mathrm{m} ; 11$ (8-16) 2 vessels $/ \mathrm{mm}^{2}$; tyloses present; simple perforation plates; alternate intervessel pits, vestured.

Axial parenchyma: few distinct, vasicentric, diffuse, few confluent and lozenge-aliform; 3-7 cells per strand.

Rays: mostly 1-seriate, few locally 2-seriate; 15 (12-18) $2 \mu \mathrm{m}$ width; 169 (100-237) $47 \mu \mathrm{m}$ height; 14 (8-17) 2 rays $/ \mathrm{mm}$; all cells procumbent, or with body cells procumbent with 1 to 2 rows of upright and square marginal cells.

Fibers: non-septate; thin to very thick-walled.

Mineral inclusions: prismatic crystals in chambered axial parenchyma cells.

Ruptures: present in rays and in fibers; especially in heartwood. 

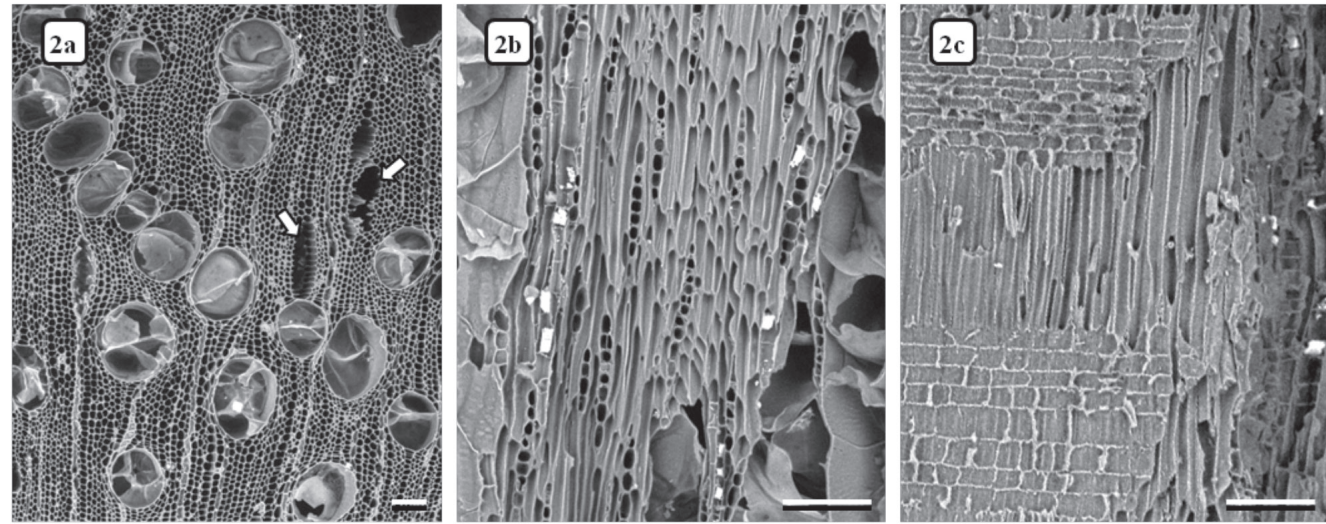

Figure 2. Plate 2. Corymbia maculata. Charcoal micrographs.

Arrows show the ruptures. Sections (a) Transverse, (b) Tangential Longitudinal, (c) Radial Longitudinal. Bars: $100 \mu \mathrm{m}$.

\section{Plate 3: Eucalyptus dunnii Maiden (Figures 3a, 3b, 3c)}

Growth rings: present, demarcated by thick-walled and radially flattened fibers.

Vessels: wood diffuse-porous; diagonal pattern; exclusively solitary (90\% or more); 112 (70-173) 23 $\mu \mathrm{m} ; 11$ (8-20) 9 vessels $/ \mathrm{mm}^{2}$; tyloses present; simple perforation plates; alternate intervessel pits, vestured.

Axial parenchyma: abundant, vasicentric, confluent, diffuse and diffuse-in-aggregates; 2-7 cells per strand.

Rays: 1-2-seriate, mostly 2-seriate; 15 (10-23) $4 \mu \mathrm{m}$ width; 173 (105-311) $59 \mu \mathrm{m}$ height; 14 (10-18) 2 rays $/ \mathrm{mm}$; all cells procumbent.

Fibers: non-septate; thin to very thick-walled.

Mineral inclusions: few prismatic crystals in tyloses and in chambered axial parenchyma cells.

Ruptures: present in rays and in few axial parenchyma cells; especially in sapwood. 

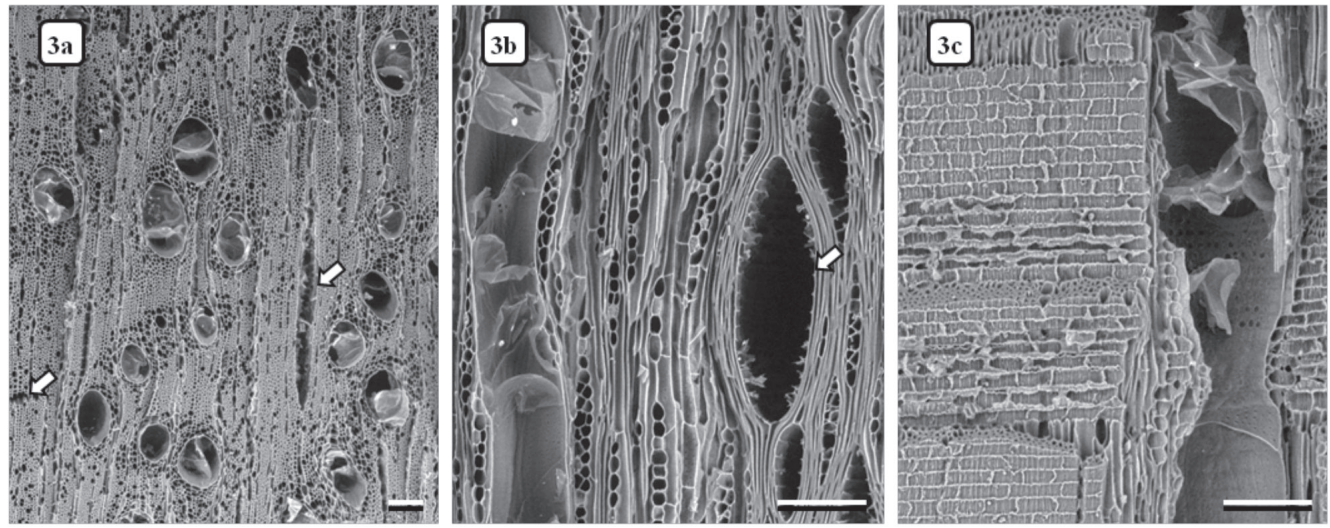

Figures 3. Plate 3. Eucalyptus dunnii. Charcoal micrographs.

Arrows show the ruptures. Sections (a) Transverse, (b) Tangential Longitudinal, (c) Radial Longitudinal. Bars: $100 \mu \mathrm{m}$.

\section{Plate 4: Eucalyptus microcorys F. Muell. (Figures 4a, 4b, 4c)}

Growth rings: present, demarcated by thick-walled and radially flattened fibers.

Vessels: wood diffuse-porous; diagonal and radial pattern; solitary and multiples; 121 (119-168) 26 $\mu \mathrm{m} ; 17$ (11-22) 15 vessels $/ \mathrm{mm}^{2}$; rare tyloses; simple perforation plates; alternate intervessel pits, vestured.

Axial parenchyma: vasicentric, confluent, lozenge-aliform, diffuse and diffuse-in-aggregates; 4-8 cells per strand.

Rays: 1-2-seriate, mostly 1-seriate; 14 (9-18) $3 \mu \mathrm{m}$ width; 208 (147-275) $47 \mu \mathrm{m}$ height; 16 (11-20) 2 rays $/ \mathrm{mm}$; all cells procumbent.

Fibers: non-septate; thick to very thick-walled.

Mineral inclusions: prismatic crystals in chambered axial parenchyma cells, more than one crystal per cell.

Ruptures: absent. 

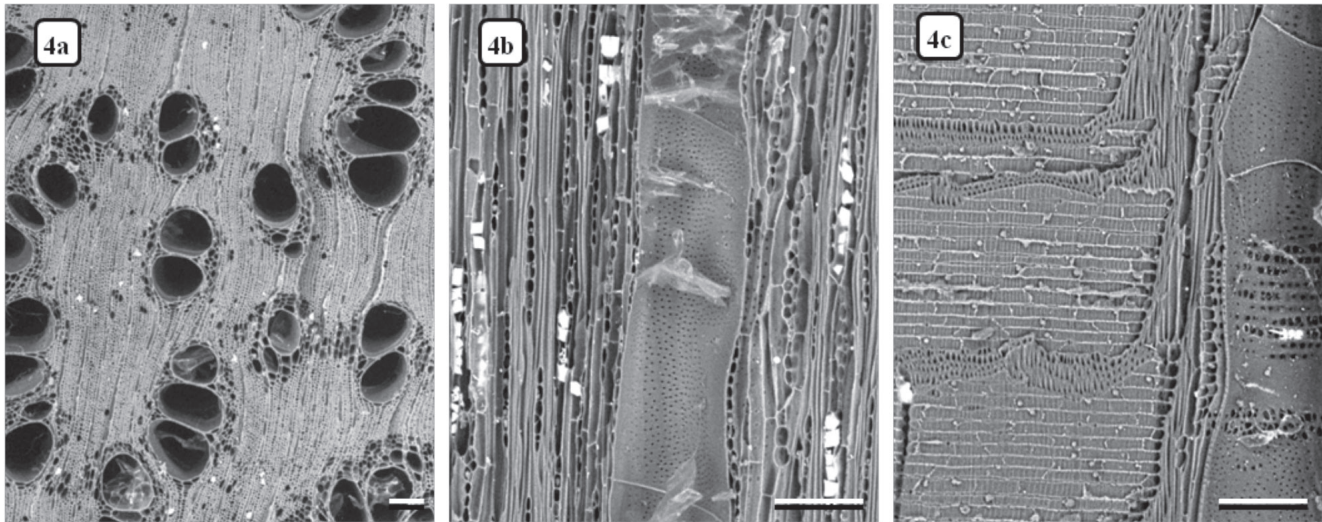

Figure 4. Plate 4. Eucalyptus microcorys. Charcoal micrographs.

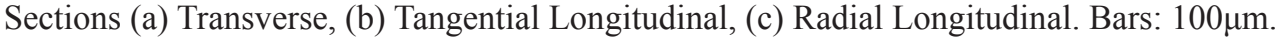

\section{Plate 5: Eucalyptus saligna Sm. (Figures 5a, 5b, 5c)}

Growth rings: present, demarcated by thick-walled and radially flattened fibers.

Vessels: wood diffuse-porous; diagonal pattern, fewer distinct in microscopy; exclusively solitary (90\% or more); 161 (110-212) $30 \mu \mathrm{m} ; 11$ (5-14) 7 vessels $/ \mathrm{mm}^{2}$; tyloses present; simple perforation plates; alternate intervessel pits, vestured.

Axial parenchyma: mostly vasicentric, but also confluent, diffuse and diffuse-in-aggregates, few lozenge-aliform; 3-8 cells per strand.

Rays: 1-2-seriate; 33 (18-46) $\mu \mathrm{m}$ width; 172 (130-224) $\mu \mathrm{m}$ height; 13 (9-17) 2 rays/mm; all cells procumbent.

Fibers: non-septate; thick to very thick-walled.

Mineral inclusions: rare prismatic crystals.

Ruptures: absent. 

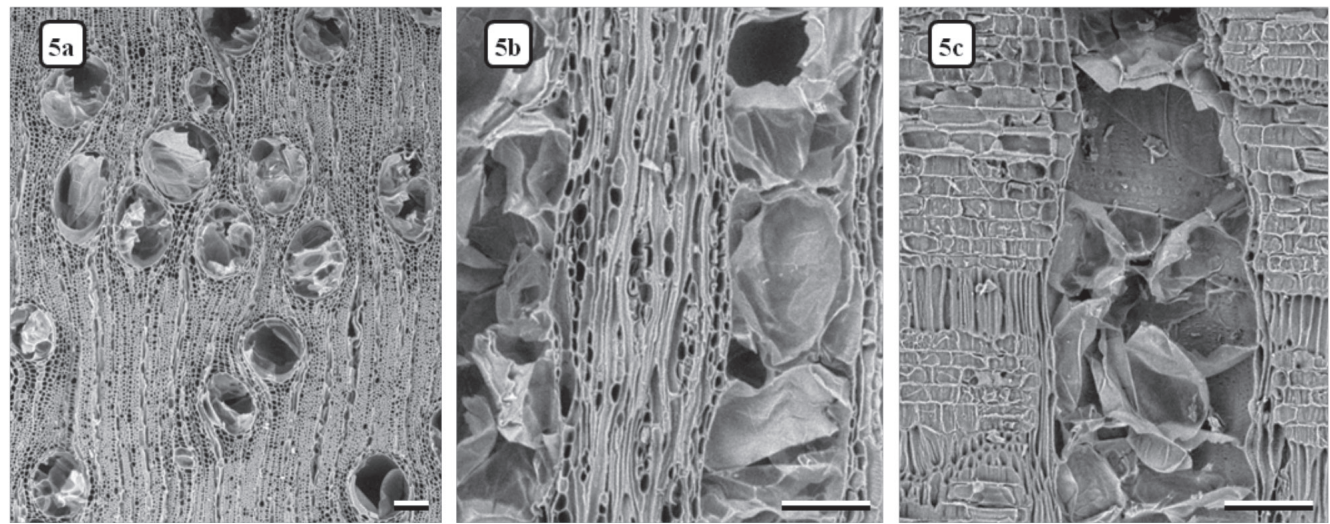

Figures 5. Plate 5. Eucalyptus saligna. Charcoal micrographs.

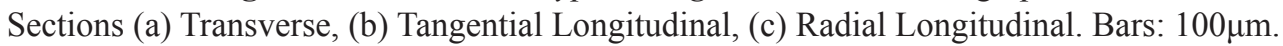

Plate 6: Eucalyptus tereticornis Sm. (Figures 6a, 6b, 6c)

Growth rings: present, demarcated by thick-walled and radially flattened fibers.

Vessels: wood diffuse-porous; diagonal pattern; exclusively solitary (90\% or more); 166 (124-218) 27 $\mu \mathrm{m} ; 9$ (5-13) 2 vessels $/ \mathrm{mm}^{2}$; tyloses present; simple perforation plates; alternate intervessel pits, vestured.

Axial parenchyma: vasicentric, confluent, diffuse and diffuse-in-aggregates, few lozenge-aliform; 4-8 cells per strand.

Rays: 1-3-seriate, mostly 2-seriate; 34 (23-44) $7 \mu \mathrm{m}$ width; 176 (132-224) $35 \mu \mathrm{m}$ height; 12 (6-15) 2 rays $/ \mathrm{mm}$; all cells procumbent.

Fibers: non-septate; thick to very thick-walled.

Mineral inclusions: rare prismatic crystals.

Ruptures: rare in rays. 

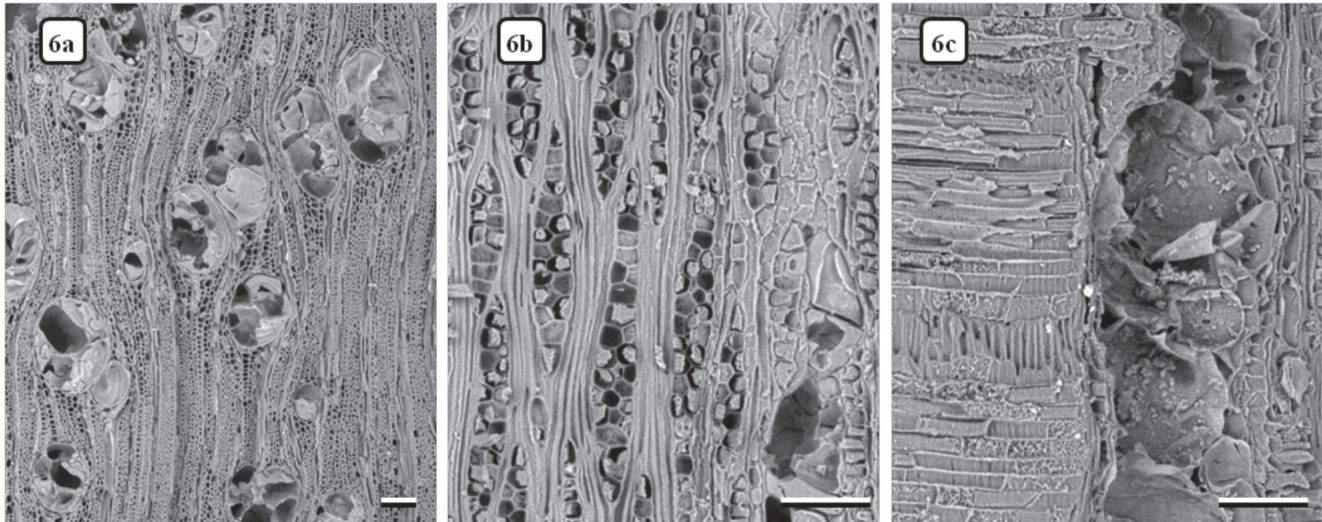

Figure 6. Plate 6. Eucalyptus tereticornis. Charcoal micrographs.

Sections (a) Transverse, (b) Tangential Longitudinal, (c) Radial Longitudinal.Bars: 100 $\mu \mathrm{m}$.

\section{Plate 7: Eucalyptus viminalis Labill. (Figures 7a, 7b, 7c)}

Growth rings: present, demarcated by thick-walled and radially flattened fibers.

Vessels: wood diffuse-porous; diagonal pattern; exclusively solitary ( $90 \%$ or more); 147 (97-187) 20 $\mu \mathrm{m} ; 10$ (5-13) 2 vessels $/ \mathrm{mm}^{2}$; tyloses present; simple perforation plates; alternate intervessel pits, vestured.

Axial parenchyma: few celled, vasicentric, confluent, diffuse and diffuse-in-aggregates and few lozenge-aliform; 3-7 cells per strand.

Rays: 1-seriate; 19 (16-21) $2 \mu \mathrm{m}$ width; 213 (121-312) $60 \mu \mathrm{m}$ height; 12 (7-17) 4 rays/mm; all cells procumbent.

Fibers: non-septate; thin to thick-walled.

Mineral inclusions: rare prismatic crystals.

Ruptures: present in rays.
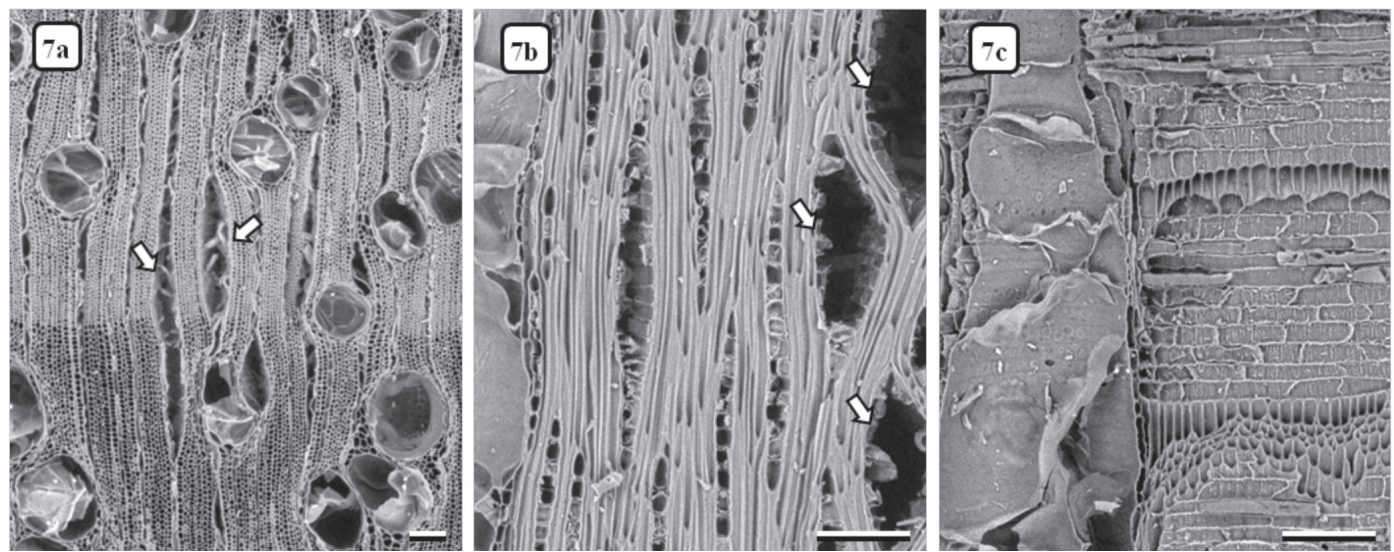

Figure 7. Plate 7. Eucalyptus viminalis. Charcoal micrographs.

Arrows show the ruptures. Sections (a) Transverse, (b) Tangential Longitudinal, (c) Radial Longitudinal. Bars: $100 \mu \mathrm{m}$. 
Table 2. Anatomical characters of the species analyzed.

\begin{tabular}{|c|c|c|c|c|c|c|c|c|c|c|c|c|c|c|}
\hline \multirow[b]{2}{*}{ Specie } & \multirow{2}{*}{$\mathrm{CC}$} & \multicolumn{3}{|c|}{ Vessels } & \multicolumn{2}{|l|}{ Axial parenchyma } & \multicolumn{5}{|c|}{ Rays } & \multirow{2}{*}{$\begin{array}{c}\text { Fibers } \\
\text { PC }\end{array}$} & \multirow{2}{*}{ IM } & \multirow{2}{*}{$\mathrm{Rp}_{\mathbf{p}}$} \\
\hline & & $\emptyset$ & Freq $/ \mathrm{mm}^{2}$ & Ty & Type & $\begin{array}{c}\text { Cells/ } \\
\text { std }\end{array}$ & Ser & Type & $\mathrm{L}$ & II & $\begin{array}{c}\begin{array}{c}\text { Freq per } \\
\mathrm{mm}\end{array} \\
\end{array}$ & & & \\
\hline C. citriodora & $\checkmark$ & $\begin{array}{c}133 \\
(83-212)\end{array}$ & $\begin{array}{c}12 \\
(8-19)\end{array}$ & $\checkmark$ & $\begin{array}{l}\text { vasicentric, confluent, } \\
\text { diffuse, diffuse-in- } \\
\text { aggregates }\end{array}$ & $4-8$ & $1-2$ & A & $\begin{array}{c}23 \\
(11- \\
38)\end{array}$ & $\begin{array}{l}193 \\
(120- \\
317)\end{array}$ & $\begin{array}{c}12 \\
(7-17)\end{array}$ & $1-2$ & $\checkmark$ & $\checkmark$ \\
\hline C. maculata & $\checkmark$ & $\begin{array}{l}149 \\
(102- \\
202)\end{array}$ & $\begin{array}{c}11 \\
(8-16)\end{array}$ & $\checkmark$ & $\begin{array}{l}\text { few distinct, vasicentric, } \\
\text { diffuse }\end{array}$ & $3-7$ & 1-(2) & $A / B$ & $\begin{array}{c}15 \\
(12- \\
18)\end{array}$ & $\begin{array}{l}169 \\
(100- \\
237)\end{array}$ & $\begin{array}{c}14 \\
(8-17)\end{array}$ & $2-3$ & $\checkmark$ & $\checkmark$ \\
\hline E. dunnii & $\checkmark$ & $\begin{array}{c}112 \\
(70-173)\end{array}$ & $\begin{array}{c}11 \\
(8-20)\end{array}$ & $\checkmark$ & $\begin{array}{l}\text { vasicentric, confluent, } \\
\text { diffuse and diffuse-in- } \\
\text { aggregates }\end{array}$ & $2-7$ & $1-2$ & A & $\begin{array}{c}15 \\
(10- \\
23)\end{array}$ & $\begin{array}{l}173 \\
(105- \\
311)\end{array}$ & $\begin{array}{c}14 \\
(10-18)\end{array}$ & $2-3$ & $\checkmark$ & $\checkmark$ \\
\hline E. microcorys & $\checkmark$ & $\begin{array}{c}121 \\
(119- \\
168)\end{array}$ & $\begin{array}{c}17 \\
(11-22)\end{array}$ & $(v)$ & $\begin{array}{l}\text { vasicentric, confluent, } \\
\text { lozenge-aliform, diffuse and } \\
\text { diffuse-in-aggregates }\end{array}$ & $4-8$ & $1-2$ & $\Lambda$ & $\begin{array}{l}14 \\
(9- \\
18)\end{array}$ & $\begin{array}{l}208 \\
(147- \\
275)\end{array}$ & $\begin{array}{c}16 \\
(11-20)\end{array}$ & $2-3$ & $\checkmark$ & \\
\hline E. saligna & $\checkmark$ & $\begin{array}{l}161 \\
(110- \\
212)\end{array}$ & $\begin{array}{c}11 \\
(5-14)\end{array}$ & $\checkmark$ & $\begin{array}{c}\text { vasicentric, but also } \\
\text { confluent, diffuse e diffuse- } \\
\text { in-aggregates }\end{array}$ & $3-8$ & $1-2$ & $A$ & $\begin{array}{c}33 \\
(18- \\
46)\end{array}$ & $\begin{array}{l}172 \\
(130- \\
224)\end{array}$ & $\begin{array}{c}13 \\
(9-17)\end{array}$ & $2-3$ & $(\checkmark)$ & - \\
\hline E. tereticornis & $\checkmark$ & $\begin{array}{l}166 \\
(124- \\
218)\end{array}$ & $\begin{array}{c}9 \\
(5-13)\end{array}$ & $\checkmark$ & $\begin{array}{l}\text { vasicentric, confluent, } \\
\text { diffuse and diffuse-in- } \\
\text { aggregates }\end{array}$ & $4-8$ & $1-3$ & A & $\begin{array}{r}34 \\
(23- \\
44)\end{array}$ & $\begin{array}{l}176 \\
(132- \\
224)\end{array}$ & $\begin{array}{c}12 \\
(6-15)\end{array}$ & $2-3$ & $(\checkmark)$ & $(\checkmark)$ \\
\hline E. viminalis & $\checkmark$ & $\begin{array}{c}147 \\
(97-187)\end{array}$ & $\begin{array}{c}10 \\
(5-13)\end{array}$ & $\checkmark$ & $\begin{array}{l}\text { vasicentric, confluent, } \\
\text { diffuse and diffuse-in- } \\
\text { aggregates }\end{array}$ & $3-7$ & 1 & A & $\begin{array}{r}19 \\
(16- \\
21)\end{array}$ & $\begin{array}{l}213 \\
(121- \\
312)\end{array}$ & $\begin{array}{c}12 \\
(7-17)\end{array}$ & 2 & $(\checkmark)$ & $\checkmark$ \\
\hline
\end{tabular}

Legend: $\checkmark$ - presence; $(\checkmark)$ - rare; $(-)$ - absence; CC - Growth rings; Vessels $-\emptyset$ - tangential diameter, Freq $/ \mathrm{mm}^{2}-$ vessels per $\mathrm{mm}^{2}$, Ty - tyloses; Axial parenchyma - Cells/std - cells per strand; Rays - Ser - width (number of cells), Type - A (all cells procumbent), B (body cells procumbent with 1 to 2 rows of upright and square marginal cell), $\mathrm{L}$ - width $(\mu \mathrm{m}), \mathrm{H}$ - height $(\mu \mathrm{m})$; Fibers $-\mathrm{PC}-$ wall thickness ( 1 - very thin-walled, 2 - thin to thick-walled, 3 - very thick-walled); IM - Mineral inclusions; $\mathbf{R p}$ - Ruptures. 


\section{DISCUSSION}

We could not find previous works reporting the anatomical characterization of charcoal made from the species analyzed in this work. The few works identifying charcoal samples from Eucalyptus spp have a special focus on the paleoenvironment (e.g. Hopkins et al. 1990).

Charcoal structure normally retains all the qualitative wood anatomy features. It presents few changes, especially in quantitative values (Prior and Gasson 1993, Gonçalves 2010). In a study of the effect of carbonization on wood structure of five species from the Brazilian cerrado, the quantitative changes found were: (i) reduction of tangential vessel diameter, (ii) increase of vessel frequency, and (iii) increase of ray frequency. But only the tangential vessel diameter differences were statistically significant, corroborating the strong basis for charcoal identification (Gonçalves et al. 2012).

The results of charcoal anatomy are very close to previous studies of wood anatomy in both qualitative and quantitative features. We compared the other species using the specialized literature and the Inside Wood database. The main differences are: (i) growth ring boundaries indistinct or absent $-C$. citriodora (Dadswell 1972), C. maculata (Kribs 1968, Dadswell 1972), E. microcorys (Kribs 1968); (ii) vessels exclusively solitary $-E$. microcorys (Kribs 1968, Alfonso 1987); (iii) ray width exclusively 1-seriate - E. saligna (Alzate 2009); (iv) ray width 1 to 3 cells - C. maculata (Kribs 1968, Dadswell 1972), E. viminalis (Dadswell 1972, Ammon 2011). These differences are common within genera (Metcalfe and Chalk 1950, Carlquist 2001), and especially in the case of growth rings, they are also influenced by ecological factors, particularly water supply (Carlquist 2001, Schweingruber 2007). Although, we strongly recommend comparing materials of similar features, enhancing the visual acuity, highlighting particularities of each material and modifications that might happen (ruptures, e.g.)

Ruptures were present in rays of C. citriodora, C. maculata, E. dunnii, E. tereticornis and E. viminalis. There are also a few ruptures in axial parenchyma cells in E. dunnii. The analysis of Quercus $a l b a$ L. revealed radial splits as the second most characteristic macroscopic feature in charcoal, similar in appearance to honeycombed wood (McGinnes et al. 1971). In Q. variabilis BL. charcoal prepared at different temperatures, the honeycombed appearance became more severe with increasing charring temperature. One of the explanations for this behavior is that an increasing charring temperature leads to a decreases cell wall thickness, volumetric shrinkage and possible ruptures. This occurred especially in multiseriate rays (Kim and Hanna 2006). The multiseriate rays in Q. robur also presented ruptures; they appeared "exploded" as if a sudden release of pressure had occurred through this region of relatively weak tissue (Braadbaart and Poole 2008). The same did not occur in Pinus sylvestris; the authors believe that it is probably due to the uniseriate rays (Braadbaart and Poole 2008). Our results demonstrate no difference between uniseriate and multiseriate rays, since the ruptures occurred in both cases. Samples of Mimosa tenuiflora and M. ophthalmocentra charcoal made at $400^{\circ} \mathrm{C}$ and higher temperatures present fissures especially among the fibers; one speculation for this behaviour is the presence of crystals may influence this fissuring (Dias Leme et al. 2010). We found ruptures only in the fibers of Corymbia maculata and we cannot associate them with the presence of crystals. Most of the species ruptures occur mainly in rays. More studies and other correlations are necessary to understand why some charcoals present these ruptures. This is particularly important in charcoal identification because sometimes the sample can be so damaged that it is hard to identify the species. 


\section{CONCLUSIONS}

There is a strong need to associate charcoal production with nature conservation and reduction of deforestation. The present work aims to contribute to control of charcoal production from native forests, by facilitating the identification of that made from eucalyptus. Considering the homogeneity of the wood anatomy of Corymbia and Eucalyptus we have not attempted to distinguish between them. We aimed to show different species of eucalypts and how to differentiate these Australian trees from native Brazilian species. We defend the sustainable use of charcoal. It might be not only from eucalyptus species but also from native species that are under sustainable forest management. We believe that charcoal anatomy is an effective tool to identify the origin of charcoal in Brazil and help to guarantee the sustainability of the charcoal supply chain.

\section{ACKNOWLEDGMENTS}

We thank Prema Tecnologia e Comércio S.A. (Rio Claro, SP) for kindly providing the samples of Corymbia and Eucalyptus. The first author is supported by CAPES (Coordenação de Aperfeiçoamento de Pessoal de Nível Superior). This work is part of her $\mathrm{PhD}$ degree at the Universidade Federal do Paraná (Brazil).

\section{REFERENCES}

Associação Brasileira de Produtores de Florestas Plantadas. ABRAF. 2012. Anuário estatístico da ABRAF 2012: ano base 2011. Brasília, DF, Brazil. 149p.

Alfonso, V.A. 1987. Caracterização anatômica do lenho e da casca das principais espécies de Eucalyptus L' Herit cultivadas no Brasil. Tese, Universidade de São Paulo, São Paulo, Brazil.

Alzate, B.A. 2009. Estrutura anatômica da madeira de clones de Eucalyptus. Revista Investigaciones Aplicadas 5:1-14.

Ammon, R. de A. 2011. Anatomia do lenho de dez espécies de Eucalyptus L'Hér. Monografia. Instituto de Florestas da Universidade Federal Rural do Rio de Janeiro, Seropédica, Brazil.

Braadbaart, F.; Poole, I. 2008. Morphological, chemical and physical changes during charcoalification of wood and its relevance to archaeological contexts. Journal of Archaeological Science 35: 2434-2445.

Brasil. 2012a. Balanço energético nacional 2012: ano base 2011. Ministério de Minas e Energia, Empresa de Pesquisa Energética, Rio de Janeiro, Brazil. 281p.

Brasil. 2012b. Bom para o Meio Ambiente, para as Pessoas e para os Negócios: Casos de Boas Práticas Sustentáveis no Brasil. Ministério do Meio Ambiente, Brazil. 236p.

Carlquist, S. 2001. Comparative Wood Anatomy. Springer Verlag, Berlín \& Heidelberg. 448 p.

Carneiro, M.S. 2008. Crítica social e responsabilização empresarial: análise das estratégias para a legitimação da produção siderúrgica na Amazônia Oriental. Caderno CRH 21:323-336.

Dadswell, H.E. 1972. The anatomy of Eucalypt woods. CSIRO For. Prod. Lab., Div. Appl. Chem. Tech. Paper 66, 28p. 
Dias-Leme, C.L.; Cartwright, C.; Gasson, P. 2010. Anatomical changes to the wood of Mimosa ophthalmocentra and Mimosa tenuiflora when charred at different temperatures. IAWA Journal 31(3): 335-351.

Euclid. 2006. Eucalypts of Australia. Third Edition. Centre for Plant Biodiversity Research, CSIRO Publishing. Australia. DVD.

Food and Agriculture Organization of the United Nations. FAO. 2012. FAOSTAT: Forestry Data. [online] <http://faostat3.fao.org/home/index.html>. [Consulted: 18 March 2013].

Gonçalves, T.A.P. 2010. Anatomia do lenho e do carvão em espécies arbóreas do cerrado no estado de São Paulo, Brasil. Botucatu. Dissertação, Universidade Estadual Paulista "Júlio De Mesquita Filho" - Faculdade de Ciências Agronômicas, Brazil.

Gonçalves, T.A.P; Marcati, C.R.; Scheel-Ybert, R. 2012. The effect of carbonization on wood structure of Dalbergia violacea, Stryphnodendron polyphyllum, Tapirira guianensis, Vochysia tucanorum, and Pouteria torta from the Brazilian cerrado. IAWA Journal 33(1):73-90.

Hill, K.D.; Johnson, L.A.S. 1995. Systematic studies in the eucalypts 7. A revision of the bloodwoods, genus Corymbia (Myrtaceae). Telopea 6:185-504.

Hopkins, M.S.; Graham, A.W.; Hewett, R.; Ash, J.; Head, J. 1990. Evidence of late Pleistocene fires and eucalypt forest from a North Queensland humid tropical rainforest site. Australian Journal of Ecology 15:345-347.

IAWA Committee. 1989. List of microscopic features for hardwood identification. IAWA Bulletin 10(2):219-332.

IBGE. Instituto Brasileiro de Geografia e Estatística. 2010. Produção da extração vegetal e da silvicultura. IBGE, Rio de Janeiro, v.25. Brasil, 50p.

IOS. Instituto Observatório Social. 2011a. A floresta que virou cinza. 31p. [online] <www. observatoriosocial.org.br>. [Consulted: 18 March 2013].

IOS. Instituto Observatório Social. 2011b. $O$ aço da devastação. 33p. [online] <www. observatoriosocial.org.br>. [Consulted: 18 March 2013].

Kim, N.H; Hanna, R. B. 2006. Morphological characteristics of Quercus variabilis charcoal prepared at different temperatures. Wood Science and Technology 40:392-401.

Kribs, D.A. 1968. Commercial foreign woods on the American market. Dover Publications, New York. 241p.

McGinnes, E.A.; Kandeel, S.A.; Szopa, P.S. 1971. Some structural changes observed in the transformation of wood into charcoal. Wood and Fiber 3(2):77-83.

Metcalfe, C. R.; Chalk, L. 1950. Anatomy of the dicotyledons. Oxford, Clarendon, 2 v. England, U.K. 1500p. 
Muñiz, G.I.B.; Nisgoski, S.; França, R.; Schardozin, F. 2012. Anatomia comparativa da madeira e carvão de Cedrelinga catenaeformis Ducke E Enterolobium schomburgkii Benth. para fins de identificação. Scientia Forestalis 40:192-297.

Prior, J.; Gasson, P. 1993. Anatomical changes on six African hardwoods. IAWA Journal 14(1):77-86.

Rozefelds, A.C. 1996. Eucalyptus phylogeny and history: a brief summary. Tasforests 8:15-26.

Schweingruber, F.H. 2007. Wood Structure and Environment. Springer-Verlag, Berlin. 279p.

World Commission on Environment and Development. WCED. 1987. Our Common Future Brundtland Report. Oxford University Press, Oxford. 300p. 